\title{
Genetic susceptibility to chlamydial salpingitis and subsequent infertility in mice
}

\author{
M. Tuffrey, F. Alexander, C. Woods and D. Taylor-Robinson \\ Division of Sexually Transmitted Diseases, Clinical Research Centre, Watford Road, Harrow, \\ Middlesex, HAl $3 U J, U K$
}

\begin{abstract}
Summary. Groups of mice from genetically defined inbred strains were infected genitally with a pathogenic human strain of Chlamydia trachomatis and their subsequent fertility was compared. The CBA, C3H $\left(H-2^{o}\right)$ and $\mathrm{C} 3 \mathrm{H} / \mathrm{He}-\mathrm{mg}\left(H-2^{k}\right)$ mice were less fertile than control mice, at least up to 6 months after infection. In contrast, fertility was not impaired in BALB/c mice or in congenic BALB/K mice, which had the $H-2^{k}$ haplotype. Reduced fertility was paralleled by the extent of histological oviductal inflammation in mice of each strain. No salpingitis was seen 21 days after infection in the BALB strains, but lesions were apparent in CBA and C3H strains up to about 70 days after inoculation and these sometimes developed into hydrosalpinges. These results indicate that susceptibility to chlamydial salpingitis and subsequent infertility is under genetic control. This control was not simply associated with the major $H-2$ gene complex, as mouse strains of the same haplotype $\left(H-2^{k}\right)$ differed in susceptibility. The fertility of BALB/c $\left(H-2^{d}\right)$ and BALB/K $\left(H-2^{k}\right)$ strains was no different from that of controls, and congenic $\mathrm{C} 3 \mathrm{H}$ mice of differing $\mathrm{H}-2$ haplotypes $\left(H-2^{k}\right.$ and $\left.H-2^{\circ}\right)$ showed reduced fertility. Although all the infected $\mathrm{F}_{1}$ $(\mathrm{BALB} / \mathrm{K} \times \mathrm{C} 3 \mathrm{H} / \mathrm{He}-\mathrm{mg})$ mice produced litters at the same rate as untreated controls, the litters were considerably smaller. This was due to the occurrence of unilateral pregnancies in the mice inoculated under the ovarian bursae and possibly also to early fetal death in mice inoculated directly in the uterus. These findings emphasize the importance of early diagnosis and treatment of infection of the lower genital tract of women.
\end{abstract}

Keywords: Chlamydia; infertility; genetics; mouse

\section{Introduction}

Epidemiological studies clearly indicate that Chlamydia trachomatis infections of the eye and genital tract with the $\mathrm{D}-\mathrm{K}$ serovars are widespread and are seen notonly in developing countries (Ballard et al., 1986) but also in the USA (Washington et al., 1986) and Europe (Mårdh, 1988). Identification of high-risk groups for targeted intervention has been based on sociological factors. Although a range of HLA-linked diseases has been described in man, only sexually acquired reactive arthritis, some cases of which have a chlamydial aetiology (Keat et al., 1987), has been strongly associated with the HLA haplotype, B27 (Keat, 1986). We have developed a mouse model of chlamydial salpingitis (Tuffrey et al., 1986a) and infertility (Tuffrey et al., 1986b) that lends itself to the investigation of possible genetic factors that might influence susceptibility to genital chlamydial infections. Many mouse strains are genetically defined and in this paper we report investigations of the natural susceptibility or resistance of several strains of mice to chlamydial salpingitis and infertility, with emphasis on embryo implantation. 


\section{Materials and Methods}

\section{Mice}

Groups of genetically defined inbred strains of mice, bred in the specific pathogen-free unit at the Clinical Research Centre, Harrow, were used: CBA $\left(H-2^{k}\right.$ haplotype), C3H/He-mg $\left(H-2^{k}\right)$ and BALB/c $\left(H-2^{d}\right)$ strains and the congenic strains $\mathrm{C} 3 \mathrm{H} / H-2^{\circ}$ and $\mathrm{BALB} / \mathrm{K}\left(H-2^{k}\right)$. A group of $\mathrm{F}_{1}$ hybrid $(\mathrm{BALB} / \mathrm{K} \times \mathrm{C} 3 \mathrm{H} / \mathrm{He}-\mathrm{mg})$ mice was also used.

\section{Chlamydia trachomatis strain}

Strain NIl (serovar E) had been isolated from the endocervix of a contact of a man with non-gonococcal urethritis. It had been passed serially in McCoy cells, and chlamydiae from the ninth passage were suspended in sucrose-phosphate medium containing $10 \%$ fetal calf serum and stored in liquid nitrogen.

\section{Inoculation of mice}

Progesterone treatment of mice is known to enhance infection of the genital tract with C. trachomatis (Tuffrey \& Taylor-Robinson, 1981) by stopping the oestrous cycle and thus preventing loss of target epithelial cells. Thus, mice were given $2.5 \mathrm{mg}$ of Depo-Provera (Upjohn, Kalamazoo, MI, USA) subcutaneously 7 days before inoculation with strain NIl or sucrose phosphate medium. The animals were anaesthetized with $0.1 \mathrm{ml}$ per $30 \mathrm{~g}$ body weight of a mixture of one part Hypnorm (Janssen Pharmaceutical Ltd, Beerse, Belgium) in two parts water and one part Hypnovel (Roche Products Ltd, Basle, Switzerland). The inoculum was introduced unilaterally, either directly into the right uterine horn (i.u.) or under the ovarian bursa (i.b.) and thus via an oviduct. These operative techniques have been described by Tuffrey et al. (1986a). Mice used for fertility studies were given about $10^{5}$ inclusion-forming units (i.f.u.) of C. trachomatis by the i.u. route or about $10^{4}$ i.f.u. by the i.b. route. Animals used for histological comparison of the severity of salpingitis were inoculated with doses of chlamydiae ranging from $10^{3}$ to $10^{4}$ i.f.u.

\section{Detection of chlamydiae}

The vagina was swabbed $I$ and 2 weeks after inoculation to confirm infection of the genital tract. Each swab was expressed in $1 \mathrm{ml}$ of cold sucrose-phosphate medium, which was then stored in liquid nitrogen until inoculation by centrifugation of cycloheximide-treated McCoy cell cultures for chlamydial isolation (Thomas et al., 1977).

\section{Histopathology}

Some animals of each strain were killed for histological examination. Samples of the oviduct and uterus were taken from the inoculated and uninoculated sides from day 7 to day 77 after inoculation. They were fixed in $10 \%$ buffered formalin and embedded in paraffin. Sections were cut through various levels of the block and stained with haematoxylin and eosin. Inflammatory changes were graded from \pm to +++ as described by Tuffrey $e t$ al. (1986a).

\section{Breeding experiments}

Males were introduced to females 2 weeks after the latter had been inoculated with chlamydiae and 3 weeks after progesterone treatment, at a stage when oestrus was due to recommence and when chlamydial lesions of the oviducts were greatest. Breeding records were documented for 6 months.

\section{Implantation study}

At the end of the 6-month breeding period, infected and control (BALB/K $\times \mathrm{C} 3 \mathrm{H}$ He-mg) $\mathrm{F}_{1}$ hybrid mice that were pregnant again were killed and opened through a ventral incision, and the number and position of all live and dead fetuses were noted.

\section{Results}

\section{Occurrence of salpingitis}

The frequency and extent of oviductal inflammation judged histologically was determined for mice of each strain. Salpingitis was seen in all the strains of mice inoculated with NIl, but to 
different extents. Salpingitis was not seen 21 days or thereafter following inoculation of the BALB strains $\left(H-2^{k}\right.$ and $\left.H-2^{d}\right)$, whereas lesions were apparent in CBA and C3H strains (both of $H-2^{k}$ haplotype) up to about 70 days after inoculation. Inflammatory changes sometimes led to hydrosalpinx formation in these strains. Of the $\mathrm{C} 3 \mathrm{H} / \mathrm{He}-\mathrm{mg}$ mice killed up to 77 days after inoculation with NII, $80 \%$ had oviductal inflammation, whereas only $35 \%$ of BALB $/ \mathrm{K}$ mice had such inflammation (Table $1, P=<0.001$, Fisher's exact test). Thus, as these strains are both $H-2^{k}$ and their susceptibility to salpingitis is different, this cannot be dependent on the $H-2^{k}$ locus. The difference in susceptibility was confirmed when $\mathrm{C} 3 \mathrm{H} / \mathrm{He}-\mathrm{mg}$ and $\mathrm{BALB} / \mathrm{K}$ mice were given similar inocula and compared for 28 days (Table 2): $11(85 \%)$ of $13 \mathrm{C} 3 \mathrm{H}$ mice showed evidence of salpingitis over this period, but only four $(25 \%)$ of $16 \mathrm{BALB} / \mathrm{K}$ mice had lesions and these were confined to the first 2 weeks $(P=0.003$, Fisher's exact test). The overall incidence of salpingitis in BALB/K and $\mathrm{BALB} / \mathrm{c}$ mice under similar circumstances (Table 2) was low and of short duration.

Table 1. Cumulative incidence of salpingitis in various strains of mice of the $H-2^{k}$ haplotype killed up to 77 days after inoculation with the Chlamydia trachomatis strain NI1

\begin{tabular}{|c|c|c|c|c|c|}
\hline \multirow[b]{2}{*}{$\begin{array}{l}\text { Mouse } \\
\text { strain }\end{array}$} & \multicolumn{2}{|c|}{$\begin{array}{c}\text { Proportion }(\%) \text { of mice with salpingitis } \\
\text { after inoculation by the }\end{array}$} & \multirow{2}{*}{$\begin{array}{c}\text { Overall } \\
\text { incidence of } \\
\text { salpingitis }\end{array}$} & \multirow[b]{2}{*}{$P$ value } & \multirow{2}{*}{$\begin{array}{l}\text { Salpingitis } \\
\text { detected up } \\
\text { to day }\end{array}$} \\
\hline & $\begin{array}{l}\text { Intrabursal } \\
\text { route }\end{array}$ & $\begin{array}{l}\text { Intrauterine } \\
\text { route }\end{array}$ & & & \\
\hline $\mathrm{C} 3 \mathrm{H} / \mathrm{He}-\mathrm{mg}$ & $31 / 33 \quad(95 \%)$ & $18 / 28(64 \%)$ & $49 / 61(80 \%)$ & & 74 \\
\hline $\mathrm{CBA}$ & $17 / 19 \quad(90 \%)$ & $7 / 15(47 \%)$ & $24 / 34(71 \%)$ & $0 \cdot 3$ & 43 \\
\hline $\mathrm{BALB} / \mathrm{K}$ & $7 / 14 \quad(50 \%)$ & $4 / 17(24 \%)$ & $11 / 31(35 \%)$ & $<0.001$ & 21 \\
\hline $\begin{array}{l}(\mathrm{BALB} / \mathrm{K}) \times \\
(\mathrm{C} 3 \mathrm{H} / \mathrm{He}-\mathrm{mg}) \mathrm{F}_{1}\end{array}$ & $4 / 4 \quad(100 \%)$ & $1 / 4 \quad(25 \%)$ & $5 / 8 \quad(63 \%)$ & $0 \cdot 4$ & $28^{*}$ \\
\hline
\end{tabular}

*Not tested later.

$P$ values are from Fisher's exact test comparing overall incidence in each strain with that in $\mathrm{C} 3 \mathrm{H} / \mathrm{He}-\mathrm{mg}$.

\section{Fertility and embryo implantation}

Oviductal inflammation reflected the fertility (proportion of mice producing litters) of the different strains (Table 3). The CBA, C3H/H-2 $2^{\circ}$ and $\mathrm{C} 3 \mathrm{H} / \mathrm{He}-\mathrm{mg}$ mice were less fertile than controls receiving sucrose phosphate medium alone up to 6 months after inoculation with NI1, but the fertility of BALB/c or the congenic BALB/K mice that had the $H-2^{k}$ haplotype was not impaired, despite the chlamydiae having infected mice of all strains inoculated. Thus, reduced fertility was not dependent on the $H-2^{k}$ locus. Although all the infected $\mathrm{F}_{1}(\mathrm{BALB} / \mathrm{K} \times \mathrm{C} 3 \mathrm{H} / \mathrm{He}-\mathrm{mg})$ mice produced litters at the same rate as mice not given chlamydiae, the former mice had considerably smaller litters.

Litters in the other inoculated mice were slightly smaller, probably as a result of unilateral pregnancies. To confirm this, the inoculated and uninoculated control hybrid mice which, because of hybrid vigour, were still becoming pregnant after the 6 month breeding period, were killed and the numbers of live fetuses and embryo implantations were counted (Table 4). The mean litter sizes ( 5 and 9 ) in the inoculated mice were considerably smaller than in the uninoculated control mice (11), even 7 months after inoculation with NI1. Nine $(82 \%)$ of 11 pregnant mice that had been inoculated intrabursally were implanted unilaterally on the non-inoculated side, while there were three unilateral pregnancies $(27 \%)$ in 11 mice that had been inoculated into the uterus. The smaller litters in the i.b.-inoculated test mice $(P<0.001)$ were mainly due to unilateral implantation; there were twice as many mice whose litters contained one or more dead fetuses in the i.u.-inoculated group, although because of the small number this was not statistically significant $(P=0 \cdot 25)$. 
M. Tuffrey et al.

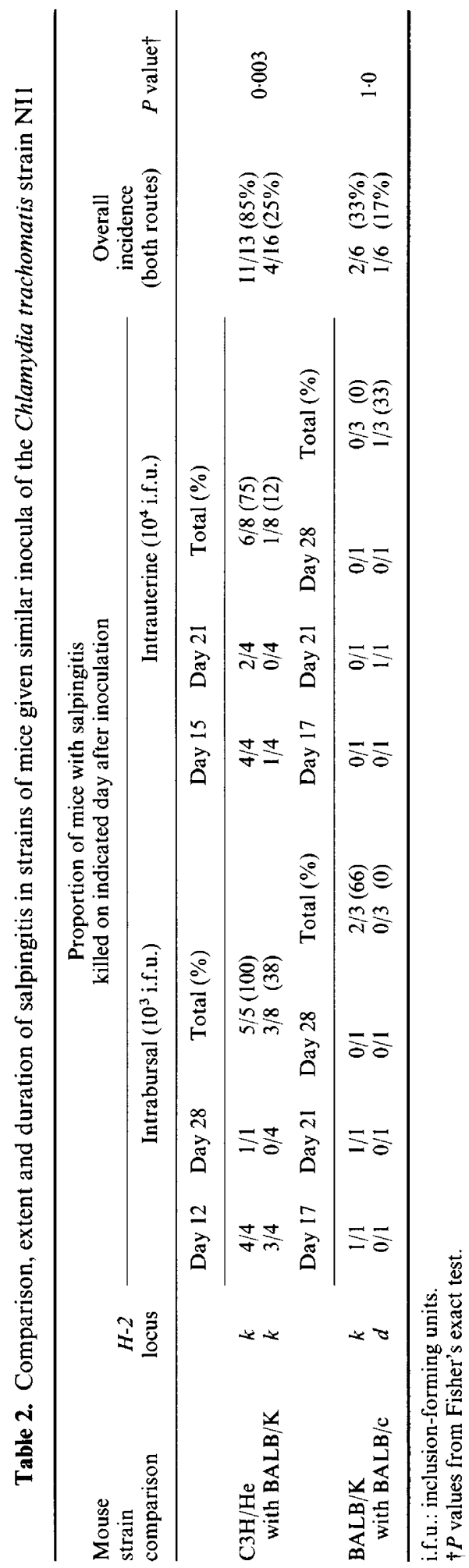

Downloaded from Bioscientifica.com at 04/26/2023 08:58:54AM 
Table 3. Fertility of six strains of mice 6 months after inoculation of the genital tract with Chlamydia trachomatis strain NII

\begin{tabular}{|c|c|c|c|c|c|c|c|}
\hline $\begin{array}{l}\text { Mouse } \\
\text { strain }\end{array}$ & $\begin{array}{c}H-2 \\
\text { locus }\end{array}$ & $\begin{array}{l}\text { Inoculum } \\
\text { and route }\end{array}$ & $\begin{array}{l}\text { No. littered/ } \\
\text { no. in group }\end{array}$ & $\begin{array}{c}\% \\
\text { littered }\end{array}$ & $P$ value $\dagger^{\dagger}$ & $\begin{array}{l}\text { Average } \\
\text { litter size }\end{array}$ & $\begin{array}{l}\text { Reduced } \\
\text { fertility }\end{array}$ \\
\hline \multirow[t]{3}{*}{ CBA } & $k$ & control ${ }^{*}$ & $7 / 8$ & 88 & & 6 & \\
\hline & & i.u. & $4 / 15$ & 27 & 0.009 & 7 & Yes \\
\hline & & i.b. & $7 / 13$ & 54 & 0.17 & 4 & Yes \\
\hline \multirow[t]{3}{*}{$\mathrm{C} 3 \mathrm{H} / \mathrm{H}-2^{\circ}$} & $o$ & control & $17 / 19$ & 89 & & 5 & \\
\hline & & i.u. & $6 / 13$ & 46 & 0.01 & 5 & Yes \\
\hline & & i.b. & $7 / 16$ & 44 & 0.009 & 4 & Yes \\
\hline \multirow[t]{3}{*}{$\mathrm{C} 3 \mathrm{H} / \mathrm{He}-\mathrm{mg}$} & $k$ & control & $25 / 27$ & 93 & & 5 & \\
\hline & & i.u. & $4 / 16$ & 25 & $<0.001$ & 4 & Yes \\
\hline & & i.b. & $6 / 16$ & 38 & $<0.001$ & 4 & Yes \\
\hline \multirow[t]{3}{*}{ BALB $/ K$} & $k$ & control & $8 / 9$ & 89 & & 6 & \\
\hline & & i.u. & $7 / 8$ & 88 & $1 \cdot 0$ & 6 & No \\
\hline & & i.b. & $7 / 8$ & 88 & 1.0 & 5 & No \\
\hline \multirow[t]{3}{*}{$\mathrm{BALB} / \mathrm{c}$} & $d$ & control & $9 / 10$ & 90 & & 6 & \\
\hline & & i.u. & $6 / 7$ & 86 & $1 \cdot 0$ & 6 & No \\
\hline & & i.b. & $6 / 7$ & 86 & $1 \cdot 0$ & 5 & No \\
\hline$(\mathrm{BALB} / \mathrm{K} \times$ & $k$ & control & $10 / 10$ & 100 & & 11 & \\
\hline \multirow[t]{2}{*}{$\mathrm{C} 3 \mathrm{H} / \mathrm{He}-\mathrm{mg}) \mathrm{F}_{1}$} & & i.u. & $15 / 15$ & 100 & $1 \cdot 0$ & 8 & Reduced \\
\hline & & i.b. & $15 / 15$ & 100 & $1 \cdot 0$ & 6 & litter size \\
\hline
\end{tabular}

*Sucrose- phosphate inoculum; i.u.: NIl inoculum, intrauterine route; i.b.: NIl inoculum, intrabursal route.

$+P$ values from Fisher's exact test.

\section{Discussion}

The results indicate, for the first time, that susceptibility to salpingitis and subsequent infertility that occurs from genital infection with a human strain of $C$. trachomatis in mice is under genetic control. This control does not seem to be associated with the $H-2$ gene complex as mouse strains with the same haplotype $\left(H-2^{k}\right)$ had differing susceptibilities. Furthermore, the fertility of BALB/c $\left(H-2^{d}\right)$ and BALB/K $\left(H-2^{k}\right)$ strains after 6 months was no different from that of controls, and congenic $\mathrm{C} 3 \mathrm{H}$ mice with differing $H-2$ haplotypes $\left(H-2^{k}\right.$ and $\left.H-2^{\circ}\right)$ showed reduced fertility. Graham \& Triglia (1986) presented similar results in relation to the respiratory tract, the outcome of inoculating mice with $C$. trachomatis intranasally also being under genetic control, and again not associated with the $H-2$ gene complex. Genetic control of resistance of mice to $C$. psittaci has also been described (Byrne et al., 1990; Fuentes \& Orfila, 1990).

It is apparent from the histological studies that i.b. inoculation resulted in a higher incidence of salpingitis than when organisms were inoculated directly into the uterus. Inoculation via the i.b. route results in severe mucous congestion accompanied by tubal oedema and loss of ciliated epithelial cells. This, in turn, is associated with failure of egg transportation to the oviduct (Tuffrey et al., 1990a). Unilateral inoculation by the i.b. route does not affect the opposite oviduct as often as inoculation by the i.u. route (Tuffrey et al., 1986a), probably because the organisms have further to travel from the original site. Thus, infection via the i.b. route often results in unilateral infertility, while inoculation into a uterine horn, which permits canalicular spread of the organisms through the uterus, can affect both oviducts (Tuffrey et al., 1986b). Consequently, the overall proportion of mice that produced litters after inoculation via the i.u. route was less than that of mice inoculated intrabursally, although the mean litter sizes of the latter mice tended to be smaller. This was particularly apparent in the $F_{1}$ hybrid between strains with differing susceptibilities and was shown to be due to implantation occurring unilaterally on the non-inoculated side. The smaller litters of hybrid mice inoculated via the i.u. route were possibly due also to fetal death. It is known that chlamydiae do not cross the mouse placenta to cause fetal damage (Tuffrey et al., 1987), but in the 
M. Tuffrey et al.

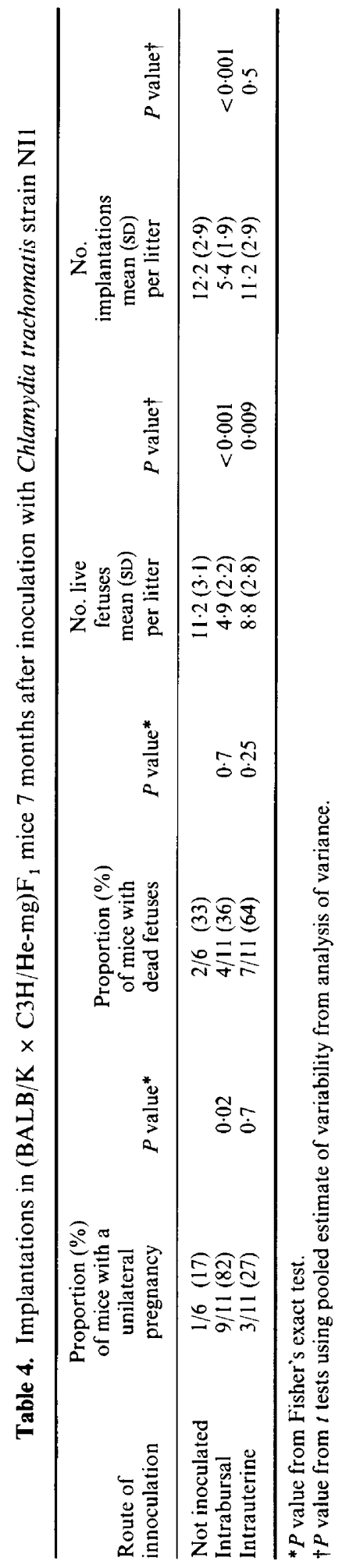


current experiments it seems that organisms already infecting the endometrial epithelium were deleterious to pregnancy outcome. Previous infection with $C$. trachomatis halved the chance of successfully establishing a pregnancy in women in a programme of in vitro fertilization and embryo replacement (Rowland et al., 1985).

This mouse model has allowed investigation of the mechanisms of chlamydial infertility. Intrabursal inoculation, resulting in unilateral implantation, may be compared to untreated chlamydial infection that has ascended to the tubes in women. In the uniovulatory human situation, this is likely to be associated with infertility or ectopic pregnancy due to tubal damage and failure of ovum transportation. Early chlamydial infection and endometritis in women, which could be comparable to intrauterine inoculation in mice, may be equally hazardous by virtue of the potential to affect pregnancy outcome. In either case, prompt diagnosis and treatment is essential. Although chlamydial salpingitis in mice is self limited, subsequent infertility continues after tubal inflammatory lesions have subsided and chlamydiae can be recovered from the genital tract. The absence of cervical shedding of organisms does not exclude the existence of salpingitis (Tuffrey et al., 1990b). These observations may be important in the human situation and re-emphasize the need for early diagnosis and treatment of infections of the lower genital tract to prevent involvement of the upper genital tract.

As susceptibility to chlamydial salpingitis and subsequent infertility in mice is under genetic control, the possibility of human genetic predisposition to chlamydial infection is worth further exploration. Its existence would be of use in the identification of high-risk groups most suitable for targeted intervention such as vaccination.

We thank C. Dore for advice and help with statistical analyses.

\section{References}

Ballard, R.C., Fehler, H.G. \& Piot, P. (1986) Chlamydial infections of the eye and genital tract in developing societies. In Chlamydial Infections, pp. 479-486. Eds D. Oriel, G. Ridgway, J. Schachter, D. TaylorRobinson \& M. Ward. Cambridge University Press, Cambridge.

Byrne, G., Padilla, M., Lacy, D., Paulnock, D. \& Guo, X.L. (1990) Mouse model for protective immunity to chlamydia. In Chlamydial Infections, pp. 236-240. Eds W. R. Bowie, H. D. Caldwell, R. P. Jones, P-A. Mårdh, G. L. Ridgway, J. Schachter, W. E. Stamm \& M. E. Ward. Cambridge University Press, Cambridge.

Fuentes, V. \& Orfila, J. (1990) Genetic control of natural resistance to Chlamydia psittaci Loth strain in mice. In Chlamydial Infections, pp. 232-235. Eds W. R. Bowie, H. D. Caldwell, R. P. Jones, P-A. Mårdh, G. L. Ridgway, J. Schachter, W. E. Stamm \& M. E. Ward. Cambridge University Press, Cambridge.

Graham, D. M. \& Triglia, T. (1986) Genetic control of responsiveness of mice to Chlamydia trachomatis pneumonitis. In Chlamydial Infections, pp. 396-399. Eds D. Oriel, G. Ridgway, J. Schachter, D. TaylorRobinson \& M. Ward. Cambridge University Press, Cambridge.

Keat, A. C. S. (1986) Chlamydia trachomatis infection in human arthritis. In Chlamydial Infections, pp. 269-279. Eds D. Oriel, G. Ridgway, J. Schacter, D. Taylor-Robinson \& M. E. Ward. Cambridge University Press, Cambridge.

Keat, A., Thomas, B., Dixey, J., Osborn, M., Sonnex, C. \& Taylor-Robinson, D. (1987) Chlamydia trachomatis and reactive arthritis: the missing link. Lancet i, $72-74$

Mårdh, P.A. (1988) The chlamydial epidemic, with especial emphasis on European perspectives. Proceedings of the European Society for Chlamydia Research 1, 3-6.

Rowland, G., Forsey, T., Moss, T., Steptoe, P., Hewitt, J. \& Darougar, S. (1985) Failure of in-vitro fertilization and embryo replacement following infection with Chlamydia trachomatis. Journal of in vitro Fertilization and Embryo Transfer 2, 151-155.

Thomas, B., Evans, R., Hutchinson, G. \& TaylorRobinson, D. (1977) Early detection of chlamydial inclusions combining the use of cycloheximidetreated McCoy cells and immunofluorescence staining. Journal of Clinical Microbiology 6, 285-292.

Tuffrey, M. \& Taylor-Robinson, D. (1981) Progesterone as a key factor in the development of a mouse model for genital-tract infection with Chlamydia trachomatis. FEMS Microbiology Letters 12, 111-116.

Tuffrey, M., Falder, P., Gale, J. \& Taylor-Robinson, D. (1986a) Salpingitis in mice induced by human strains of Chlamydia trachomatis. British Journal of Experimental Pathology 67, 605-616.

Tuffrey, M., Falder, P., Gale, J., Quinn, R. \& TaylorRobinson, D. (1986b) Infertility in mice infected genitally with a human strain of Chlamydia trachomatis. Journal of Reproduction and Fertility 78, 251-260.

Tuffrey, M., Falder, P., Gale, J. \& Taylor-Robinson, D. (1987) Failure of Chlamydia trachomatis to pass transplacentally to fetuses of TO mice infected during pregnancy. Journal of Medical Microbiology 24, 1-5. 
Tuffrey, M., Alexander, F., Inman, C. \& Ward, M.E. (1990a) Correlation of infertility with altered tubal morphology and function in mice with salpingitis induced by a human genital-tract isolate of Chlamydia trachomatis. Journal of Reproduction and Fertility 88, 295-305.

Tuffrey, M., Alexander, F. \& Taylor-Robinson, D. (1990b) Severity of salpingitis in mice after primary and repeated inoculation with a human strain of Chlamydia trachomatis. Journal of Experimental Pathology 71, 403-410.
Washington, A.E., Johnson, R.E., Sanders, L.L., Barnes, R.C. \& Alexander, E.R. (1986) Incidence of Chlamydia trachomatis infections in the United States: using reported Neisseria gonorrhoeae as a surrogate. In Chlamydial Infections, pp. 487-490. Eds D. Oriel, G. Ridgway, J. Schachter, D. TaylorRobinson \& M. Ward. Cambridge University Press, Cambridge.

Received 14 January 1991 